\title{
Physicochemical and sensory characteristics of milk from cows in different lactation stages and calving orders
}

\author{
Características físico-química e sensoriais do leite bovino em \\ diferentes estágios de lactação e ordens de parto
}

\author{
Mayara Leilane de Jesus Barreto ${ }^{1}$; Adriano Henrique do Nascimento Rangel'; \\ Maria Helena Constantino Spyrides ${ }^{3}$; Gelson Santos Difante ${ }^{2}$; \\ Dorgival Morais de Lima Júnior ${ }^{4 *}$
}

\begin{abstract}
Knowledge of the variation in milk composition is essential for determining milk quality, which is defined by several organoleptic properties. This study evaluated the effect of lactation stage and calving order on the physicochemical composition and sensory characteristics of milk from primiparous and multiparous lactating dairy cows. Milk samples were collected monthly from December 2011 to May 2012. Data were analyzed using ANOVA followed by Tukey's test $(\mathrm{p}<0.05)$. Milk production (PROD), somatic cell count (SCC), and milk urea nitrogen (MUN) were significantly higher in multiparous cows, whereas the casein to total protein ratio (C/TP) was significantly higher in primiparous cows. All milk components except for non-fat dry solids (NDE) were significantly affected by lactation stage. Body condition score (BCS) was not affected by calving order or lactation stage. Color was the only sensory attribute affected by calving order. In conclusion, the physicochemical properties and sensory attributes of milk were affected by calving order and lactation stage.
\end{abstract}

Key words: Lactation stage. Milk quality. Primiparous. Multiparous.

\section{Resumo}

O conhecimento da variação na composição do leite é essencial para determinar sua qualidade, a qual é definida por várias propriedades organolépticas. Este estudo avaliou o efeito do estágio de lactação e ordem de parto sobre a composição físico-química e as características organolépticas do leite de vacas leiteiras primíparas e multíparas. As amostras de leite foram coletadas mensalmente no período de dezembro de 2011 a maio de 2012. Os dados foram analisados por meio de análise de variância (ANOVA), seguida pelo teste de Tukey $(\mathrm{p}<0,05)$. A produção de leite (PROD), contagem de células somáticas (CCS) e nitrogênio ureico no leite (NUL) foram significativamente mais elevados em vacas multíparas, ao passo que a caseína e sua proporção na proteína total do leite $(\mathrm{C} / \mathrm{PT})$ foi significativamente mais elevada em vacas primíparas. Todos os componentes do leite foram significativamente afetados pela fase de lactação, exceto para os sólidos não gordurosos (SNG). Escores de condição corporal (ECC) não foram afetados pela ordem de parto ou estágio de lactação. A cor foi o único atributo sensorial afetado pela ordem de parto. Em conclusão, as propriedades físico-químicas e sensoriais do leite atributos foram afetadas pela ordem de parto e estágio de lactação.

Palavras-chave: Dias em leite. Primíparas. Multíparas.

1 Discente do Programa de Pós-graduação em Produção Animal, Universidade Federal do Rio Grande do Norte, UFRN, Macaíba, RN, Brasil. E-mail: mayleila_jinha@yahoo.com.br

2 Profs. Associados, UFRN, Unidade Acadêmica Especializada em Ciências Agrárias, UAECA, Macaíba, RN, Brasil. E-mail: adrianohrangel@yahoo.com.br; gdifante@hotmail.com

3 Prof ${ }^{a}$ Associado, UFRN, Departamento de Ciências Atmosféricas e Climáticas, Natal, RN, Brasil. E-mail: spyrides@ccet.ufrn.br

4 Prof. Adjunto, Universidade Federal de Alagoas, UFAL, Campus Arapiraca, Arapiraca, AL, Brasil. E-mail: juniorzootec@yahoo. com.br

* Author for correspondence 


\section{Introduction}

Knowledge of the variation in milk composition is essential for evaluating milk quality, which is defined by several organoleptic properties (LANGONI et al., 2011; OLIVEIRA et al., 2011). According to Rangel et al. (2013), milk properties are affected by multiple genetic, environmental, and physiological factors. The main physiological factors affecting milk properties include age at first calving, lactation stage, calving order, and cow age, with milk production generally increasing as cows get older (RIBEIRO et al., 2009). Grande et al. (2009) argued that lactation stage is the main physiological factor associated with variations in milk composition.

Sensory analysis is an interdisciplinary science that utilizes panels of human assessors to evaluate the sensory characteristics and acceptability of food products (TEIXEIRA, 2009). Differences in dry matter composition of raw milk from cows in different lactation stages and calving orders may significantly affect the sensory characteristics of milk. Thus, this study aimed to evaluate the physicochemical composition (fat, protein, lactose, total solids, and urea nitrogen) and sensory characteristics (odor, flavor, residual taste, color, texture, and overall acceptability) of milk from cows in different stages of lactation and calving orders.

\section{Materials and Methods}

The study was conducted from December 2011 to May 2012 at a 550-ha commercial dairy farm in the coastal region of São José de Mipibu, $31 \mathrm{~km}$ south of Natal, the capital of the state of Rio Grande do Norte, Brazil. The region is characterized by a tropical rainy climate with well-defined dry and rainy seasons. The rainy season extends from April to June and has an average rainfall of $1.268,2 \mathrm{~mm}$. The average temperature is $27.1{ }^{\circ} \mathrm{C}$ and average relative humidity is $76 \%$ (IDEMA, 2013).

The farm has 24 Girolando cows (3/4 and 7/8) that produce an average of $2500 \mathrm{~L} \mathrm{day}^{-1}$. The feeding system is semi-intensive rotational grazing of
Tangola (Cynodon spp.) and Tifton 85 (Brachiaria spp.) grasses. Additionally, animals were fed a concentrate supplement consisting of corn meal, soybean, and cassava throughout the study period.

Cows in early lactation were selected to reduce the risk of animals finishing lactation before the end of the experiment. Twelve primiparous and 12 multiparous cows were selected, totaling 24 animals. However, because some animals had to be replaced, repeated monthly measurements were taken during the study.

Days in milk (DIM) was calculated from the calving data, and lactation was grouped into three phases: up to 60 days of lactation (DIM < 60), between 61 and 210 days of lactation $(61<$ DIM $<210$ ), and DIM $>210$ days. Cow body condition score (BCS) was determined on a 1-5 numerical scale with increments of 0.25 , as proposed by Wildman et al. (1982) and Edmonson et al. (1989).

Milk samples from two milkings were collected monthly on the same day and transferred from the milk meter of an automated milking machine into 40-mL sterile plastic bottles containing Bronopol ${ }^{\circledR}$ preservative for analysis of milk composition and somatic cell count (SCC). Immediately after collection, samples were stored at $5{ }^{\circ} \mathrm{C}$ and sent to a laboratory accredited by the Brazilian Network of Milk Quality (BNMQ).

The concentrations of fat, protein, lactose, and total solids were determined by infrared Fourier transform spectroscopy analysis using a MilkoScan ${ }^{\mathrm{TM}}$ FT milk analyzer (Foss Electric A/S., Hillerød, Denmark). The concentration of milk urea nitrogen (MUN) was determined enzymatically using a ChemSpec $150^{\circledR}$ analyzer (Bentley Instruments Inc., Chaska, MN, USA) and results were expressed in $\mathrm{mg} / \mathrm{dL}$. Somatic cell counts (SCC) were determined by flow cytometry using an automated Somacount $300^{\circledR}$ flow cytometer (Bentley Instruments Inc.).

Milk samples used for sensory analysis were taken from each animal and mixed to obtain one 2-L composite sample. Samples were placed in sterile glass jars and cooled to temperatures below $5{ }^{\circ} \mathrm{C}$. 
Next, the milk was pasteurized by heating to $90{ }^{\circ} \mathrm{C}$ for 15 min followed by rapid cooling to $45^{\circ} \mathrm{C}$, as described by Medeiros et al. (2010).

Sensory analysis of an acceptable standard was done in the auditorium of the Technology Center at the Federal University of Rio Grande do Norte (UFRN), Natal, Brazil, by 50 untrained panelists aged 15-60 years and consisting of UFRN faculty and students. Milk from primiparous and multiparous cows was rated in separate trials. Each panelist received three plastic cups labeled with random three-digit codes containing $50 \mathrm{~mL}$ of milk cooled to $5{ }^{\circ} \mathrm{C}$. Bottled water and toast were provided to clean the palate between samples. Sensory analysis tests were performed in individual booths away from noise and odors from 8:00 am-12:00 noon.

The following sensory attributes were evaluated: odor, flavor (odor and taste), residual taste, color, texture, and overall acceptability. Attribute intensities were scored on a structured 9-point hedonic scale where 1 represents "dislike extremely" and 9 represents "like extremely", as proposed by Chaves and Sproesser (2005).

The acceptability index (AI) was calculated for each attribute as described by Teixeira et al. (1987): $\mathrm{AI}=$ average score (AS)/highest score (HS) x 100 . Mean scores represent the simple average of the values assigned by the panelists.
Data were analyzed using descriptive statistics, ANOVA, and Tukey's test for multiple comparisons of means. Wilks' multivariate analysis was used for the sensorial analysis in order to determine the main components and compare the milk from primiparous and multiparous cows. All analyses were performed using SAS ${ }^{\circledR}$. Differences between means were considered significant at $\mathrm{p}<0.05$.

\section{Results and Discussion}

Mean values of milk production and composition variables are presented in Table 1. Most variables were not affected by calving order. However, some variables, including milk production (PROD), somatic cell count (SCC), milk urea nitrogen (MUN), and the casein to total protein ratio (C/TP), were significantly affected by calving order.

Milk production was significantly higher in multiparous cows than in primiparous cows. A similar result was also reported by Souza et al. (2010), who evaluated the effect of calving order on milk production in cows and found higher milk production in $3^{\text {rd }}$ and $4^{\text {th }}$ lactation cows, followed by $2^{\text {nd }}$ lactation cows, whereas primiparous cows and $5^{\text {th }}$ lactation cows were less productive. Similar findings were reported by Noro et al. (2006), Andrade et al. (2007), and Ribeiro et al. (2009).

Table 1. Analysis of variance and comparisons of means and significance test to variables according to the calving order.

\begin{tabular}{lccc}
\hline \multirow{2}{*}{ Variables $^{1}$} & \multicolumn{2}{c}{ Calving order } & \multirow{2}{*}{ Value of $\mathrm{p}(<0.05)$} \\
\cline { 2 - 3 } & Primiparous & Multiparous & 0.000 \\
PROD (kg) & $7.51^{\mathrm{b}} \pm 2.58$ & $10.98^{\mathrm{a}} \pm 2.49$ & 0.569 \\
FAT (\%) & $3.21^{\mathrm{a}} \pm 0.91$ & $3.45^{\mathrm{a}} \pm 1.15$ & 0.742 \\
PROT (\%) & $3.28^{\mathrm{a}} \pm 0.39$ & $3.27^{\mathrm{a}} \pm 0.26$ & 0.908 \\
LACT (\%) & $4.63^{\mathrm{a}} \pm 0.30$ & $4.44^{\mathrm{a}} \pm 0.26$ & 0.424 \\
TS (\%) & $12.04^{\mathrm{a}} \pm 1.03$ & $12.03^{\mathrm{a}} \pm 1.16$ & 0.357 \\
NFS (\%) & $8.83^{\mathrm{a}} \pm 0.49$ & $8.58^{\mathrm{a}} \pm 0.32$ & 0.000 \\
SCC $\left(\times 10^{3} \mathrm{cel} \mathrm{mL}^{-1}\right)$ & $169.40^{\mathrm{b}} \pm 501.90$ & $509.40^{\mathrm{a}} \pm 730.60$ & 0.001 \\
MUN (mg dL & $12.51^{\mathrm{b}} \pm 3.35$ & $14.91^{\mathrm{a}} \pm 4.52$ & 0.491 \\
CAS (\%) & $2.55^{\mathrm{a}} \pm 0.33$ & $2.50^{\mathrm{a}} \pm 0.22$ & 0.000 \\
PCTMP $(\%)$ & $77.74^{\mathrm{a}} \pm 1.72$ & $76.60^{\mathrm{b}} \pm 1.39$ & \\
\hline
\end{tabular}

${ }^{1}$ Production (PROD), fat (FAT), protein (PROT), lactose (LACT), total solids (TS), non-fat solids (NFS), somatic cell count (SCC), milk urea nitrogen (MUN), casein (CAS) and percentage of casein in total protein (PCTMP).

* The original data were transformed using $\log 10$

a, b Averages with lowercase letters in the same row differ $(\mathrm{P}<0.05)$ by $\mathrm{t}$ test. 
Milk production correlates positively with body size (AKERS et al., 2006; DANIELS et al., 2009). Thus, the higher milk production observed in multiparous cows may be associated with mammary gland development (i.e., increased number of milksecreting cells) and body growth (i.e., higher feed intake capacity). Conversely, primiparous cows have not reached physiological maturity and their mammary system does not support a large volume of milk.

Somatic cell counts (SCC) are generally used as an indicator of udder health, especially to monitor mastitis in dairy herds. In this study, SCC was significantly higher in multiparous cows than in primiparous cows. In fact, SCC are usually higher in cows with a greater number of lactations. Older cows with more lactations are more likely to have intramammary infections, as they have been at risk of being exposed to causative pathogens of mastitis for a longer period (ZAFALON et al., 2005; De VLIEGHER et al., 2012). Differences in SCC may also be explained by differences in the mammary epithelium of old cows and heifers, since the more developed mammary epithelium of older cows has more secretory tissue and more epithelial desquamation.

Milk urea nitrogen (MUN) also was significantly higher in multiparous than in primiparous cows. It has been suggested that normal MUN values should range between 10 and $16 \mathrm{mg} \mathrm{dL}^{-1}$ (ROY et al., 2011). Galvão Júnior et al. (2010) evaluated the effect of calving order on the physicochemical composition of Zebu milk and found a positive correlation between MUN and calving order, which the authors attributed to differences in nitrogen metabolism between cows and heifers.

The casein to total protein ratio $(\mathrm{C} / \mathrm{TP})$ was significantly higher in primiparous cows than in multiparous cows. The higher casein concentration may be related to the lower milk production in primiparous cows.

All milk composition variables were significantly affected by lactation stage except for non-fat dry extract (NDE) (Table 2). The variation in milk composition may be explained by changes in the mammary gland secretory epithelium of lactating cows and the higher feed intake during lactation.

Table 2. Analysis of variance and comparisons of means and significance test to production (PROD), fat (FAT), protein (PROT), lactose (LACT), total solids (TS), non-fat solids (NFS), somatic cell count (SCC), milk urea nitrogen (MUN), casein (CAS) and percentage of casein in total protein (PCTMP) according to the lactation stage.

\begin{tabular}{|c|c|c|c|c|}
\hline \multirow{2}{*}{ Variables $^{1}$} & \multicolumn{3}{|c|}{ Lactation stage } & \multirow{2}{*}{$\begin{array}{c}\text { Value of } \mathrm{p} \\
(<0.05)\end{array}$} \\
\hline & $\mathrm{DIM}<60$ & $61<$ DIM $>210$ & $\mathrm{DIM} \geq 210$ & \\
\hline PROD (kg) & $9.52^{\mathrm{a}} \pm 3.15$ & $9.28^{\mathrm{a}} \pm 2.99$ & $7.00^{\mathrm{b}} \pm 3.32$ & 0.000 \\
\hline FAT $(\%)$ & $3.04^{b} \pm 0.65$ & $3.37^{\mathrm{b}} \pm 1.10$ & $4.09^{\mathrm{a}} \pm 1.27$ & 0.003 \\
\hline PROT (\%) & $3.13^{\mathrm{c}} \pm 0.25$ & $3.30^{b} \pm 0.34$ & $3.54^{\mathrm{a}} \pm 0.13$ & 0.000 \\
\hline LACT (\%) & $4.69^{\mathrm{a}} \pm 0.19$ & $4.50^{b} \pm 0.31$ & $4.32^{\mathrm{c}} \pm 0.29$ & 0.000 \\
\hline TS (\%) & $11.76^{\mathrm{b}} \pm 0.70$ & $12.06^{\mathrm{b}} \pm 1.16$ & $12.91^{\mathrm{a}} \pm 1.10$ & 0.000 \\
\hline NFS $(\%)$ & $8.71^{a} \pm 0.34$ & $8.69^{\mathrm{a}} \pm 0.46$ & $8.82^{\mathrm{a}} \pm 0.38$ & 0.669 \\
\hline $\operatorname{SCC}^{*}\left(\mathrm{x} 10^{3} \mathrm{cel} \mathrm{mL}^{-1}\right)$ & $149.10^{\mathrm{b}} \pm 198.40$ & $414.10^{\mathrm{a}} \pm 742.30$ & $187.90^{\mathrm{ab}} \pm 167.30$ & 0.005 \\
\hline MUN (mg dL-1) & $12.13^{\mathrm{b}} \pm 3.39$ & $14.32^{\mathrm{a}} \pm 4.35$ & $12.40^{\mathrm{ab}} \pm 1.99$ & 0.001 \\
\hline $\mathrm{CAS}^{*}(\%)$ & $2.43^{\mathrm{c}} \pm 0.21$ & $2.54^{\mathrm{b}} \pm 0.29$ & $2.79^{a} \pm 0.10$ & 0.000 \\
\hline PCTMP* $(\%)$ & $77.50^{\mathrm{b}} \pm 1.68$ & $76.94^{b} \pm 1.61$ & $78.75^{\mathrm{a}} \pm 1.11$ & 0.000 \\
\hline
\end{tabular}

* The original data were transformed using $\log 10$

${ }^{\mathrm{a}, \mathrm{b}}$ Averages with lowercase letters in the same row differ $(\mathrm{P}<0.05)$ by $\mathrm{t}$ test. 
Milk production (PROD) was higher in early to mid-lactation but was significantly lower at the end of lactation, following the standard lactation curve of cows: milk yield peaks in early lactation, becomes stable at mid-lactation, and decreases at the end of lactation.

Fat (FAT) and total solids (TS) contents were higher in the final third of lactation. This result can be explained by the increased concentration of milk components caused by the reduction in milk production at the end of lactation. In addition, Mendes et al. (2010) ascribed the production of more dilute milk to cow nutrition, as high concentrations of propionic and butyric acids in concentrates fed to lactating cows have been shown to reduce milk fat content (MENDES et al., 2010).

Protein (PROT) and casein (CAS) levels and the casein to total protein ratio $(\mathrm{C} / \mathrm{TP})$ were significantly different across lactation stages, with the highest averages observed in the final third of lactation. Because milk production and, consequently, nutritional requirements are lower at the end of lactation, the energy/protein ratio in milk is generally more balanced then.

Milk urea nitrogen (MUN) values were highest at mid-lactation, when milk yield was highest. According to Obitsu and Taniguchi (2009), optimal MUN values vary with milk production, but levels below $12 \mathrm{mg} / \mathrm{dl}$ and above $18 \mathrm{mg} / \mathrm{dL}$ may indicate inadequate nutrition.

In light of the role of lactose (LACT) in the osmotic regulation of milk, the variation in lactose content observed in this study may be explained by lactation stage. In fact, lactose concentrations decline at the end of lactation when milk yield is lower. According to Pollott et al. (2014), increased desquamation (greater shedding of the epithelium) of the mammary gland secretory epithelium in the final third of lactation increases SCC, resulting in a decline in the concentration of lactose, which passes from the mammary gland into the blood due to changes in the permeability of cell membranes.

Somatic cell count (SCC) was highest in midlactation. SCC increases gradually toward the end of lactation because of shedding of the mammary gland secretory epithelium. Moreover, the decline in milk yield in late lactation causes an apparent increase in the number of cells because of the higher concentration of cells in a lower volume of milk (RANGEL et al., 2011, 2013). Moreover, epithelial renewal in the mammary gland via apoptosis may also increase the number of defense cells such as somatic cells at the end of lactation. According to Capuco et al. (2001), epithelial cells undergo apoptosis after the peak of lactation because of the decline in secretory activity in the absence of mammary growth.

SCC and milk component values for all of the calving orders and lactation stages met the minimum requirements in Normative Instruction 62 (IN \# 62/2011) (BRASIL, 2011) for northeastern Brazil, including those for protein $(2.9 \%)$, fat $(3.0 \%)$, nonfat dry extract (8.4\%), and the upper threshold for $\operatorname{SCC}\left(7.5 \times 10^{5}\right.$ cells $\left.\mathrm{mL}^{-1}\right)$.

Body condition score (BCS) was not affected by calving order or lactation stage (Table 3 ), indicating that cows were fed adequate diets in the different lactation stages, during each of which animals have specific requirements.

Table 3. Indices of body condition score for the three (03) stages of lactation and the two (02) calving orders.

\begin{tabular}{lcc}
\hline Variables & & BCS \\
\hline \multirow{2}{*}{ Lactation phases $(\mathrm{p}=0.20)$} & Stage 1 & $3.46^{\mathrm{a}}$ \\
& Stage 2 & $3.38^{\mathrm{a}}$ \\
Calving order $(\mathrm{p}=0.19)$ & Stage 3 & $3.50^{\mathrm{a}}$ \\
& Primiparous & $3.38^{\mathrm{a}}$ \\
\hline
\end{tabular}

${ }^{\mathrm{a}, \mathrm{b}}$ Averages with lowercase letters in the same row differ $(\mathrm{P}<0.05)$ by $\mathrm{t}$ test. 
Color, which was the only sensory attribute for its characteristic yellowish-opaque color. affected by calving order (Table 4; $<<0.05$ ), may Further studies on milk color are needed, as it is have been affected by the higher casein to total an organoleptic property with a large influence on protein ratio $(\mathrm{C} / \mathrm{TP})$ in primiparous cows (Table acceptance, not only of raw milk, but also of other 1). Casein micelles are the primary contributors dairy products such as cheese (OLIVEIRA et al., to the light scattering in milk that is responsible 2011).

Table 4. Mean and standard deviation of the sensory attributes according to the calving order.

\begin{tabular}{|c|c|c|c|}
\hline \multirow{2}{*}{ Variables } & \multicolumn{2}{|c|}{ Calving order } & \multirow{2}{*}{ Value of $p(<0.05)$} \\
\hline & Primiparous & Multiparous & \\
\hline Odor & $7,18^{a} \pm 1,48$ & $6,89^{a} \pm 1,80$ & 0,29 \\
\hline Flavor & $7,03^{a} \pm 1,42$ & $6,98^{a} \pm 1,68$ & 0,32 \\
\hline Taste & $6,93^{a} \pm 1,63$ & $6,98^{a} \pm 1,92$ & 0,45 \\
\hline After taste & $6,33^{a} \pm 1,68$ & $6,36^{\mathrm{a}} \pm 1,90$ & 0,27 \\
\hline Color & $7,11^{\mathrm{b}} \pm 1,63$ & $6,11^{a} \pm 2,13$ & 0,00 \\
\hline Texture & $6,75^{a} \pm 1,78$ & $6,27^{a} \pm 2,18$ & 0,08 \\
\hline Overall Acceptance & $7,12^{\mathrm{a}} \pm 1,48$ & $6,85^{\mathrm{a}} \pm 1,92$ & 0,26 \\
\hline
\end{tabular}

${ }^{\mathrm{a}, \mathrm{b}}$ Averages with lowercase letters in the same row $\operatorname{differ}(\mathrm{P}<0.05)$ by $\mathrm{t}$ test.

Mean panelist ratings for sensory attributes are listed in Table 5, and the distribution of sensory attributes in the PCA plot is shown in Figure 1. Panelist ratings for the color of milk from multiparous cows did not achieve the $70 \%$ minimum required for sensory approval (ALVES et al., 2009), indicating that it should be improved. Although texture was also rated low, it achieved the minimum required for acceptance.

Table 5. Acceptance indices of the sensory attributes according to the calving order.

\begin{tabular}{lcc}
\hline & Primiparous & Multiparous \\
\cline { 2 - 3 } Odor & $79.78 \mathrm{a}$ & $76.56 \mathrm{a}$ \\
Flavor & $78.11 \mathrm{a}$ & $77.56 \mathrm{a}$ \\
Taste & $77.00 \mathrm{a}$ & $77.56 \mathrm{a}$ \\
After taste & $70.33 \mathrm{a}$ & $70.67 \mathrm{a}$ \\
Color & $79.00 \mathrm{a}$ & $67.89 \mathrm{~b}$ \\
Texture & $75.00 \mathrm{a}$ & $69.67 \mathrm{a}$ \\
Overall Acceptance & $79.11 \mathrm{a}$ & $76.11 \mathrm{a}$ \\
\hline
\end{tabular}


Figure 1. Principal component analysis of cow's milk from primiparous and multiparous lactating.

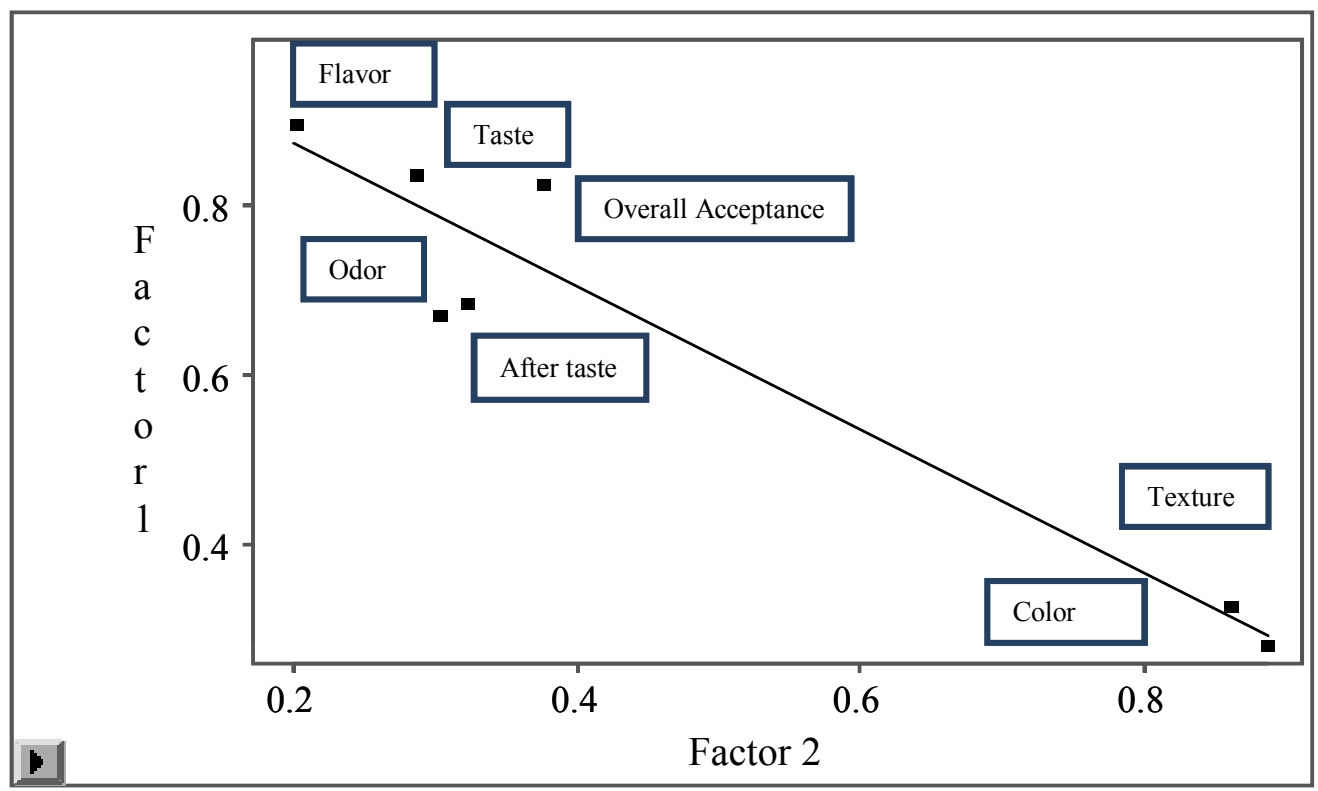

\section{Conclusion}

Milk production, composition, and sensory attributes were affected by calving order and lactation stage of cows.

\section{References}

AKERS, R. M. Major advances associated with hormone and growth factor regulation of mammary growth and lactation in dairy cows. Journal of Dairy Science, Ilinois, v. 89 , n. 3, p. 1222-1234, 2006.

ALVES, L. L.; RICHARDS, N. S. P. S.; BECKER, L. V.; ANDRADE, D. F.; MILANI, L. I. G.; REZER, A. P. S.; SCIPIONI, G. C. Aceitação sensorial e caracterização de frozen yogurt de leite de cabra com adição de cultura probiótica e prebiótico. Ciência Rural, Santa Maria, v. 39, n. 3, p. 2595-2600, 2009.

ANDRADE, L. M.; EL FARO, L.; CARDOSO, V. L.; ALBUQUERQUE, L. G.; CASSOLI, L. D.; MACHADO, P. F. Efeitos genéticos e de ambiente sobre a produção de leite e a contagem de células somáticas em vacas holandesas. Revista Brasileira de Zootecnia, Viçosa, MG, v. 36, n. 5, p. 343-349, 2007.

BRASIL. Ministério da Agricultura, Pecuária e do Abastecimento. Instrução Normativa $\mathrm{n}^{\circ}$ 62, 2011. Regulamento técnico de produção, identidade e qualidade do leite tipo a, o regulamento técnico de identidade e qualidade de leite cru refrigerado, o regulamento técnico de identidade e qualidade de leite pasteurizado e o regulamento técnico da coleta de leite cru refrigerado e seu transporte a granel. Brasília, 30 de dezembro de 2011, Seção 1, p. 6. Disponível em: <http://sistemasweb. agricultura.gov.br/sislegis/action/detalhaAto.do?method $=$ consultarLegislacaoFederal $>$. Acesso em: 23 set. 2014.

CAPUCO, A. V.; WOOD, D. L.; BALDWIN, R.; MCLEOD, K.; PAAPE, M. J. Mammary cell number, proliferation, and apoptosis during a bovine lactation: relation to milk production and effect of bST. Journal of Dairy Science, Illinois, v. 84, n. 7, p. 2177-2187, 2001.

CHAVES, J. B. P.; SPROESSER, R. L. Práticas de laboratório de análise sensorial de alimentos e bebidas. Viçosa, MG: UFV, 2005. $81 \mathrm{p}$.

DANIELS, K. M.; Mc GILLIARD, M. L.; MEYER, M. J.; VAN AMBURGH, M. E.; CAPUCO, A. V.; AKERS, R. M. Effects of body weight and nutrition on histological mammary development in Holstein heifers. Journal of Dairy Science, Illinois, v. 92, n. 8, p. 499-505, 2009.

De VLIEGHER, S.; FOX, L. K.; PIEPERS, S.; MC DOUGALL, S.; BARKEMA, H. W. Mastitis in dairy heifers: Nature of the disease, potential impact, prevention, and control. Journal of Dairy Science, Illinois, v. 95, n. 9, p. 1025-1040, 2012.

EDMONSON, A. J.; LEAN, I. J.; WEAVER, L. D. A body condition scoring chat for Holstein dairy cows. Journal of Dairy Science, Illinois, v. 72, n. 4, p. 68-78, 1989.

GALVÃO JÚNIOR, J. G. B.; RANGEL, A. H. N.; MEDEIROS, H. R.; SILVA, J. B. A.; AGUIAR, E. M.; MADRUGA, R. C.; LIMA JÚNIOR, D. M. Efeito da 
produção diária e da ordem de parto na composição físico-química do leite de vacas de raças zebuínas. Acta Veterinaria Brasilica, Mossoró, v. 4, n. 3, p. 25-30, 2010.

GRANDE, P. A.; SANTOS, G. T.; RIBEIRO, H.; DAMASCENO, J. C.; ALCALDE, C. R.; BARBOSA, O. R.; HORST, J. A.; SANTOS, F. S. Monitoring the nutritional and reproductive state of dairy cows through the presence of urea in milk. Brazilian Archives of Biology and Technology, Curitiba, v. 52, n. 5, p. 249-258, 2009.

\section{INSTITUTO DE DESENVOLVIMENTO} SUSTENTÁVEL E MEIO AMBIENTE - IDEMA. Perfil do seu município. São José do Mipibú: [s.n.], 2013. Disponível em: <http://adcon.rn.gov.br/ACERVO/ idema/DOC/DOC000000000016673.PDF>. Acesso em: 29 mar. 2016.

LANGONI, H.; PENACHIO, D. S.; CITADELLA, J. C. C.; LAURINO, F.; FACCIOLI-MARTINS, P. Y.; LUCHEIS, S. B.; MENOZZI, B. D.; SILVA, A. V. Aspectos microbiológicos e de qualidade do leite bovino. Pesquisa Veterinária Brasileira, Rio de Janeiro, v. 31, n. 4, p. 1059-1065, 2011.

MEDEIROS, A. C. L.; MEDEIROS, K. C. B.; MEDEIROS, M. F.; CORREIA, R. T. P. Avaliação comparativa do efeito do tratamento térmico e temperatura de incubação sobre o perfil de acidificação dos leites Bovino, Bubalino e Caprino. Revista Brasileira de Produtos Agroindustriais, Campina Grande, v. 12, n. 2, p. 105-114, 2010.

MENDES, C. G.; SAKAMOTO, S. M.; SILVA, J. B. A.; JÁCOME, C. G. M.; LEITE, A. I. Análises físico-químicas e pesquisa de fraude no leite informal comercializado no município de Mossoró, RN. Ciência Animal Brasileira, Goiânia, v. 11, n. 4, p. 349-356, 2010.

NORO, G.; GONZÁLEZ, F. H. D.; CAMPOS, R.; DÜRR, J. W. Fatores ambientais que afetam a produção e a composição do leite em rebanhos assistidos por cooperativas no Rio Grande do Sul. Revista Brasileira de Zootecnia, Viçosa, MG, v. 35, n. 4, p. 1129-1135, 2006.

OBITSU, T.; TANIGUCHI, K. Quantitative comparison of diversity and conformity in nitrogen recycling of ruminants. Asian Australasian Journal of Animal Science, Seoul, v. 22, n. 6, p. 440-447, 2009.

OLIVEIRA, C. J.; LOPES JÚNIOR, W. D.; QUEIROGA, R. C.; GIVISIEZ, P. E.; AZEVEDO, P. S.; PEREIRA, W. E.; GEBREYES, W. A. Risk factors associated with selected indicators of milk quality in semiarid northeastern Brazil. Journal of Dairy Science, Illinois, v. 94, n. 4, p. 3166-3175, 2011.

POLLOTT, G. E.; WILSON, K.; JERRAM, L.; FOWKES, R. C.; LAWSON, C. A noninvasive method for measuring mammary apoptosis and epithelial cell activation in dairy animals using microparticles extracted from milk. Journal of Dairy Science, Illinois, v. 97, n. 6, p. 5017-5022, 2014.

RANGEL, A. H. N.; ARAÚJO, V. M.; BEZERRA, K. C.; BARRETO, M. L. J.; MEDEIROS, H. R.; LIMA JÚNIOR, D. M. Avaliação da qualidade do leite cru com base na contagem de células somáticas em rebanhos bovinos comerciais no estado do Rio Grande do Norte, Brasil. Archivos Veterinary Science, Porto Alegre, v. 18, n. 3, p. 40-45, 2013.

RANGEL, A. H. N.; OLIVEIRA, J. P. F.; ARAÚJO, V. M.; BEZERRA, K. C.; MEDEIROS, H. R.; LIMA JÚNIOR, D. M.; OLIVEIRA, C. G. F. Influência do estádio de lactação sobre a composição do leite de búfalas. Acta Veteterinaria Brasilica, Mossoró, v. 5, n. 2, p. 306-310, 2011.

RIBEIRO, A. B.; TINOCO, A. F. F.; LIMA, G. F. C.; GUILHERMINO, M. M.; RANGEL, A. H. N. Produção e composição do leite de vacas de vacas Gir e Guzerá nas diferentes ordens de parto. Revista Caatinga, Mossoró, v. 22, n. 3, p. 312-323, 2009.

ROY, B.; BRAHMA, B.; GHOSH, S.; PANKAJ, P. K.; MANDAL, G. Evaluation of milk urea concentration as useful indicator for dairy herd management: a review. Asian Journal Animal Veterinary Advances, Dubai, v. 6, n. 1, p. 1-19, 2011.

SOUZA, R.; SANTOS, G. T.; VALLOTO, A. A.; SANTOS, A. L.; GASPARINO, E.; SILVA, D. C.; SANTOS, W. B. R. Produção e qualidade do leite de vacas da raça Holandesa em função da estação do ano e ordem de parto. Revista Brasileira de Saúde e Produção Animal, Salvador, v. 11, n. 3, p. 484-495, 2010.

TEIXEIRA, E.; MEINERT, E. M.; BARBETTA, P. A. Análise sensorial de alimentos. Florianópolis: UFSC, 1987. $182 \mathrm{p}$.

TEIXEIRA, L. V. Análise sensorial na indústria de alimentos. Revista do Instituto Laticínios Cândido Tostes, Juiz de Fora, v. 64, n. 1, p. 12-21, 2009.

WILDMAN, E. E.; JONES, G. M.; WAGNER, P. E.; BOMAN, R. L. A dairy body condition scoring system and its relationship to selected production characteristics. Journal of Dairy Science, Illinois, v. 65, n. 2, p. 495-501, 1982.

ZAFALON, L. F. A.; NADER FILHO, A.; AMARAL, L. A.; OLIVEIRA, J. V.; RESENDE, F. D. Alterações da composição e da produção de leite oriundo de quartos mamários de vacas com e sem mastite subclínica de acordo com o estágio e o número de lactações. Arquivo do Instituto Biológico, São Paulo, v. 72, n. 4, p. 419-426, 2005. 